UDC 330.59

LBC 60.54

\title{
HOUSING SATISFACTION AS THE IDENTIFIER OF LIFE QUALITY IN THE REGION ${ }^{1}$
}

\author{
Olga V. Shinyaeva
}

Ulyanovsk State Technical University, Ulyanovsk, Russian Federation

\author{
Ekaterina R. Akhmetshina
}

Ulyanovsk State Technical University, Ulyanovsk, Russian Federation

Tatyana V. Klyueva

Ulyanovsk State Technical University, Ulyanovsk, Russian Federation

\begin{abstract}
Meeting housing needs is an essential part of social policy in each region. Housing for the family is the most important need in different times, and in modern conditions housing status is the basic social indicator of the level and quality of life. The quality of life of the population includes a whole range of characteristics related to the satisfaction of material and cultural needs, in this context, we consider the housing needs of the population.

The article is aimed at identifying the nature of housing conditions and housing needs of the population in the context of improving the quality of life. In order to consider housing satisfaction as an identifier of quality of life the analysis of changes in the content of this phenomenon is carried out. At the end of the last century the quality of life was considered at the junction of the categories "lifestyle" and "way of life". The development of the theory of quality of life reveals the complex nature of this phenomenon: it is created by the full potential of society, when social practices in various fields (housing, consumer, industrial, cultural) contribute to improving the quality of life of the population.

The article concludes that the mass privatization of housing has not solved the housing problem; to determine the level and quality of housing conditions, the author's sociological study. All the surveyed families are divided by the criterion "housing satisfaction": "completely satisfied", "partly satisfied", "dissatisfied". The greatest dissatisfaction is demonstrated by young people and multi-sex families; but these are people who lack the necessary means to solve this problem. The population attitude to improving the quality of life is a reference point for federal and regional governments: despite the formal provision of housing, the development of its quality characteristics and improving comfort is at an early stage.

Key words: quality of life, standard of living, housing affordability, housing conditions, housing needs, housing satisfaction.

УДК 330.59

ळ ББК 60.54

\section{УДОВЛЕТВОРЕННОСТЬ ЖИЛЬЕМ}

КАК ИДЕНТИФИКАТОР КАЧЕСТВА ЖИЗНИ В РЕГИОНЕ 1
\end{abstract}

\section{Ольга Викторовна Шиняева}

Ульяновский государственный технический университет, г. Ульяновск, Российская Федерация

Екатерина Рифовна Ахметшина

Ульяновский государственный технический университет, г. Ульяновск, Российская Федерация

Татьяна Валерьевна Клюева

Ульяновский государственный технический университет, г. Ульяновск, Российская Федерация 
Аннотация. Удовлетворение потребности в жилище является важнейшим направлением социальной политики каждого региона. Жилье для семьи - важнейшая потребность в разные времена, а в современных условиях жилищный статус выступает базовым социальным индикатором уровня и качества жизни. Качество жизни населения включает целый комплекс характеристик, связанных с удовлетворением материальных и культурных потребностей, в этом контексте мы рассматриваем жилищные потребности населения.

Статья нацелена на выявление характера жилищных условий и потребностей населения в жилье в контексте улучшения качества жизни. Для рассмотрения удовлетворенности жильем в качестве идентификатора качества жизни осуществлен анализ изменения содержания данного явления. В конце прошедшего столетия качество жизни рассматривалось на стыке категорий «стиль жизни» и «образ жизни». Развитие теории качества жизни раскрывает комплексный характер этого явления: оно создается всем потенциалом общества, когда социальные практики в разных областях (жилищной, потребительской, производственной, культурной) вносят вклад в улучшение качества жизни населения.

В статье сделан вывод о том, что массовая приватизация жилья не решила жилищный вопрос. Для определения уровня и качества жилищных условий проведено авторское социологическое исследование. Все обследованные семьи делятся по критерию «удовлетворенность жильем» на три типа: «удовлетворенные полностью», «удовлетворенные частично», «неудовлетворенные». Самую высокую неудовлетворенность демонстрируют молодые люди и многопоколенные семьи, но именно у них нет необходимых средств для решения этого вопроса. Установки населения на повышение качества жизни являются ориентиром для федеральных и региональных органов управления: несмотря на формальную обеспеченность жильем, развитие его качественных характеристик и повышение комфортности находятся на начальной стадии.

Ключевые слова: качество жизни, уровень жизни, доступность жилья, жилищные условия, потребности в жилье, удовлетворенность жильем.

Обеспеченность жильем и его доступность напрямую влияют на уровень и качество жизни населения, поскольку приобретение жилья требует значительных денежных средств, а также связано с решением других жизненных проблем больших социальных групп. Удовлетворение потребностей в жилище является важнейшим направлением социальной политики каждого региона, это подтверждается обоснованием в стратегических программах прямого влияния жилищных условий на демографическое и социально-экономическое развитие территорий, укрепление человеческого капитала. В современных условиях жилищный статус семьи выступает базовым социальным индикатором ее благополучия и, не смотря на кажущуюся достижимость, не является легко изменяемым показателем.

Исходя из особенностей удовлетворения потребностей в жилье разных групп и слоев, нами сформулирована следующая проблема: с одной стороны, доступность жилья является важнейшим индикатором качества жизни населения и основанием социальной политики регионов; с другой стороны, в условиях активного жилищного строительства далеко не все количественные и качественные потребности в жилье достижимы. Цель данной ста- mьи - выявить характер влияния доступности жилищных условий на улучшение качества жизни населения.

Качество жизни включает целый комплекс характеристик, связанных с удовлетворением материальных и культурных потребностей: качество питания и одежды; качество образования, здравоохранения и сферы досуга; качественное обеспечение безопасности, труда, доступа к информации; наконец, качество и комфорт жилища. В этом контексте мы рассматриваем жилищные потребности населения.

Разработке теоретических подходов исследования места благополучия жилища в реализации жизненных стратегий посвящены исследования на разных этапах развития социума. Еще Аристотель утверждал, что «к созданию государства людей побуждает и сознание общей пользы, поскольку на долю каждого приходится участие в прекрасной жизни (dzenkalos); это по преимуществу и является целью как для объединенной совокупности людей, так и для каждого человека в отдельности. Люди объединяются и ради самой жизни» $[1$, с. 454].

В дальнейшем теория обеспечения качества жизни получила развитие в работах исследователей, которые в числе основных кри- 
териев назвали удовлетворенность жильем. Согласно точке зрения А. Пигу, понятие индивидуального благосостояния не сводится к его материальным составляющим. Кроме «максимума полезности от потребления, благосостояние включает и такие составляющие, как характер работы, условия окружающей среды, взаимоотношения с другими людьми, положение в обществе, жилищные условия и безопасность» [19, p. 56]. Эти показатели с теми или иными вариациями стали использоваться при изучении качества жизни социальных групп.

Понятие «качество жизни» в социологическую науку вошло в середине XX в. для описания социально-бытовых, социально-культурных аспектов жизни и с тех пор претерпело смысловую трансформацию. По мнению американских социологов, качество жизни обеспечивает представителей различных социальных групп возможностью потребления благ и услуг, достижений индустриального общества и должно анализироваться на стыке категорий «стиль жизни» и «образ жизни». Дж. К. Гэлбрейт определил «качество жизни» как синоним общественных благ, получаемых личностью с ростом ее интеллектуальных потребностей [16, p. 32]. В структуре качества жизни социологи стали выделять условия работы и качество жилища; удовлетворение потребностей в жилье становится одним из основных критериев качества жизни.

Российские социологи внесли свой вклад в развитие теории качества жизни и его составляющих. Л.А. Беляева предложила авторскую интерпретацию этого явления: «Качество жизни - это комплексная характеристика условий жизнедеятельности населения, которая выражается в объективных показателях и субъективных оценках удовлетворения материальных, социальных и культурных потребностей и связана с восприятием людьми своего положения в зависимости от культурных особенностей, системы ценностей и социальных стандартов, существующих в обществе» [3, с. 35]. В предложенной методике измерения качества жизни населения индекс удовлетворенности жильем входит в число основных индикаторов комплексного индекса благосостояния.

Исследования в регионах современной России показали, что наиболее уязвимыми в реальной действительности являются экзистенциальные потребности населения: потребности в безопасности жизни, реализуемые через комфорт; постоянство условий жизни, реализуемое через улучшение жилищных условий и уверенность в будущем. Данные потребности являются базовыми и формируют основу для развития инновационной экономики, стабильного общества в целом. Социологи Татарстана, анализируя качество жизни в условиях рыночной экономики, подчеркивают необходимость двойной ответственности за его реализацию - государства и индивидов. «Наличие у домашних хозяйств собственного (или в наем) жилья, отвечающего всем требованиям и со стороны государства, и личностным критериям качественного проживания, является необходимым фактором такого развития» [13, с. 264], «обеспеченность жильем и собственностью - один из основных критериев благосостояния и качества жизни населения» [8, с. 96].

Современный город рассматривается учеными как особая социально-территориальная форма организации общественного производства, где осуществляется не только производство вещей, но и «производство самих людей» - их ценностей, потребностей, культурного капитала, представлений об условиях жизни. В городе усиливаются процессы «атомизации» - распада традиционных связей; при этом новые формы общения по месту жительства заполняют «пустоты общения», связанные с другими сферами.

Вопросы обеспеченности жильем относятся к числу важнейших проблем в мировых масштабах. Программа Организации Объединенных Наций по населенным пунктам $(\mathrm{OOH}-$ Хабитат) содействует устойчивому развитию территорий и осуществляет международные кампании, одна из которых - всемирная кампания по обеспечению гарантий владения жильем. Специальный комитет $\mathrm{OOH}$ предлагает содействие правительствам, помощь в выполнении обязательств по обеспечению «надлежащего жилья для всех»- одной из основных целей Хабитат [21, p. 4]. По данным доклада $\mathrm{OOH}$, в России вопросы, связанные с обеспечением жильем в городском пространстве, стоят особенно остро, это связано с высоким уровнем урбанизации страны (см. табл. 1). 
Удовлетворенность жильем как идентификатор качества жизни в регионе

Таблица 1

Процесс урбанизации в разных странах

\begin{tabular}{|l|r|r|r|r|r|c|}
\hline \multirow{2}{*}{ Регион } & \multicolumn{2}{|c|}{ Городское население (млн чел.) } & \multicolumn{2}{c|}{ Уровень урбанизации (\%) } \\
\cline { 2 - 7 } & 2005 & 2015 & $\begin{array}{c}2025 \\
\text { прогноз) }\end{array}$ & 2005 & 2015 & $\begin{array}{c}2025 \\
\text { (прогноз) }\end{array}$ \\
\hline Мир & 3199013 & 3957285 & 4705774 & 49,1 & 54,0 & 58,2 \\
\hline Развитые страны & 920702 & 985831 & 1034150 & 75,8 & 78,3 & 80,4 \\
\hline Развивающиеся страны & 2278311 & 2971454 & 3671623 & 43,0 & 49,0 & 54,0 \\
\hline Менее развитые страны & 198147 & 295178 & 427084 & 26,5 & 31,4 & 36,6 \\
\hline Россия & $\mathbf{1 0 5 7 3 7}$ & $\mathbf{1 0 5 1 6 4}$ & $\mathbf{1 0 3 2 0 0}$ & $\mathbf{7 3 , 5}$ & $\mathbf{7 4 , 0}$ & $\mathbf{7 5 , 3}$ \\
\hline Бразилия & 154190 & 174508 & 191032 & 82,8 & 85,7 & 87,8 \\
\hline Индия & 329517 & 419939 & 525459 & 29,2 & 32,7 & 37,0 \\
\hline Китай & 560518 & 779479 & 947540 & 42,5 & 55,6 & 65,4 \\
\hline ЮАР & 28717 & 34663 & 39313 & 59,5 & 64,8 & 69,4 \\
\hline США & 238319 & 265361 & 292222 & 79,9 & 81,6 & 83,3 \\
\hline
\end{tabular}

Примечание. Источник: [21, p. 196].

Программа развития городов включает актуальную идею «революции эффективности», в соответствии с которой стратегия перманентного и экспоненциального экономического роста должна смениться практикой «устойчивого» развития условий жизни, в том числе жилищных. При переходе к устойчивому развитию городских систем резко возрастает роль местного самоуправления в обеспечении комфортной среды обитания. Среда города принимается как сеть взаимосвязанных компонентов, которую требуется не только сохранять, но и развивать. Экологические, жилищные вопросы и проблемы организации общежития являются важным фактором, способным объединить усилия горожан для решения конкретных проблем.

В среднем только десятая часть горожан полностью удовлетворена всеми обстоятельствами своей жизни; около половины - частично [2, с. 212]. Отношение к собственному положению меняется в зависимости от региона, характера потребностей и возможностей их удовлетворения. Возрастает значение жилищных - риски «большого города» компенсируются качеством «ближнего пространства»: собственной квартиры, дома, двора. Комфортная социальная среда, развитие жилищной сферы, участие жителей в контроле качества жилищно-коммунального обслуживания входят в основные направления оценки качества жизни населения, предложенные группой социологов Института экономики Уральского отделения РАН [7, с. 186].

Анализ бюджетов домохозяйств показывает, что рост обеспеченности жильем про- изошел в первую очередь в верхней части распределения населения: доля домашних хозяйств, у которых на одного проживающего приходится свыше 40 кв. м, выросла за два последних десятилетия на 8 \% (см. табл. 2). Доля семей с крайне малой жилой площадью (менее 9 кв. м на одного проживающего), сократилась почти в три раза и составляет 2,9\%. Однако при этом жилище, площадь которого составляет менее 15 кв. м на человека, - почти у каждой четвертой семьи.

Неравенство жилищных условий более $60 \%$ населения считают явным подтверждением социальной несправедливости. Половина малоимущих домашних хозяйств России живет в тесных домах или квартирах, когда на одного члена семьи приходится менее 15 кв. м [11, с. 24]. Они в силу низких доходов не могут самостоятельно решить проблему жилья и только в случае постановки на учет в качестве нуждающихся могут рассчитывать на помощь государства. Это не только российская проблема. Оценивая доступность жилья в Канаде, Дж. Луффман отмечает: «Несмотря на то что стоимость жилья в разных регионах Канады отличается, доход - главный фактор, влияющий на его доступность и недоступность» [18, p. 24].

Обеспеченность жильем и его качество уверенно входят в перечень критериев, которые свидетельствуют о материальном успехе отдельного человека или его семьи. Удельный вес россиян, признающих данный аргумент, за последние 15 лет вырос на $20 \%$ и составляет $62 \%$ (см. табл. 3). По результатам опроса «Левады-Центра», «хорошее жи- 
Распределение домашних хозяйств по площади жилых помещений на одного проживающего (\% от общего числа домохозяйств)

\begin{tabular}{|l|r|r|r|r|r|r|r|r|r|c|}
\hline $\begin{array}{c}\text { Площадь } \\
\text { на одного } \\
\text { проживающего }\end{array}$ & 1995 & 2000 & 2005 & 2010 & 2011 & 2012 & 2013 & 2014 & 2015 & $\begin{array}{c}2015, \\
\text { малоимущие } \\
\text { домохозяйства }\end{array}$ \\
\hline до 9,0 & 8,8 & 5,5 & 6,2 & 3,0 & 3,3 & 3,5 & 3,0 & 3,0 & 2,9 & 9,3 \\
\hline $9,1-13,0$ & 19,6 & 16,9 & 17,1 & 13,8 & 13,2 & 13,0 & 12,8 & 12,4 & 12,8 & 25,8 \\
\hline $13,1-15,0$ & 13,3 & 11,3 & 12,7 & 9,2 & 9,2 & 9,3 & 9,3 & 8,9 & 8,9 & 15,1 \\
\hline $15,1-20,0$ & 24,4 & 22,0 & 18,3 & 19,6 & 19,2 & 19,0 & 19,7 & 19,9 & 19,8 & 24,9 \\
\hline $20,1-25,0$ & 13,7 & 15,4 & 13,9 & 15,6 & 15,8 & 15,2 & 14,8 & 15,7 & 15,1 & 12,8 \\
\hline $25,1-30,0$ & 20,2 & 8,9 & 9,3 & 10,4 & 9,8 & 10,3 & 9,9 & 10,2 & 9,9 & 5,7 \\
\hline $30,1-40,0$ & & 10,2 & 10,3 & 12,7 & 12,6 & 12,5 & 12,6 & 12,5 & 13,1 & 4,2 \\
\hline 40,1 и более & & 9,8 & 12,2 & 15,7 & 16,8 & 17,3 & 17,7 & 17,2 & 17,5 & 2,3 \\
\hline
\end{tabular}

Примечание. Источники: [10, с. 176; 11, с. 24].

Таблица 3

Критерии признания материальной успешности в оценках россиян (\% от числа опрошенных; $n=1601)$

\begin{tabular}{|l|c|c|c|c|}
\hline \multicolumn{1}{|c|}{ Показатели } & 2001 & 2005 & 2010 & 2015 \\
\hline Хорошее жилье & 42 & 43 & 58 & 62 \\
\hline $\begin{array}{l}\text { Свободное расходование денег, не считая каж- } \\
\text { дую копейку }\end{array}$ & 53 & 50 & 50 & 51 \\
\hline Возможность дать детям хорошее образование & 30 & 37 & 38 & 29 \\
\hline Большие сбережения & 24 & 25 & 27 & 29 \\
\hline Хорошее питание & 33 & 43 & 28 & 28 \\
\hline Хороший автомобиль & 13 & 14 & 21 & 25 \\
\hline Отдых за границей, путешествия & 15 & 15 & 15 & 22 \\
\hline Хорошая дача, загородный дом & 7 & 9 & 10 & 16 \\
\hline Ничего, кроме денег & 6 & 11 & 4 & 5 \\
\hline Модная одежда & 4 & 4 & 3 & 4 \\
\hline
\end{tabular}

Примечание. Источник: [9].

лье» возглавляет список элементов достатка в сознании российских граждан; его признают главным условием благополучия более $60 \%$ россиян. В последние годы эта характеристика жизни опередила даже финансовую обеспеченность семьи - «свободное расходование денег».

Массовая приватизация жилья в 1990-е гг. привела к тому, что большая часть жилого фонда находится в собственности граждан. Собственниками занимаемого жилья к 2013 г. стали $79 \%$ домохозяйств (в 2006 г. было 73 \%). В результате этих процессов по численности домохозяйств, проживающих в собственном жилье, Россия обошла Америку. По данным Бюро цензов США, за последние полтора десятилетия наблюдается смена типа домовладения: американцы чаще обращаются к рынку аренды жилья, а не его покупки. Доля арендаторов жилья в США достигла 35 \% [15], соответственно, домовладельцы - две трети американских домохозяйств. При этом американский исследователь Д. Хулчански считает, что основные факторы, влияющие на доступность жилья, - структура расходов домохозяйства, наличие государственной поддержки жилищных программ, социальный оптимизм домохозяйств - их готовность платить ипотечные взносы, платежи за съем жилья $[17$, p. 471$]$.

Обобщая все положения о качестве жизни и его составляющих, мы пришли к собственным выводам. Понятие «качество жизни» подразумевает установку на анализ особых духовных характеристик жизни индивида или социальной группы. К этим характеристикам следует отнести стереотипы восприятия и оценки уровня, условий и образа жизни, степень принятия либо критического переосмысления основных жизненных планов и стратегий жизнедеятельности, наличие и полноту реализации социально-статусных и коммуни- 
кационных потребностей личности. Для более полного достижения нашей цели - конкретизации реальных жилищных условий и их связи с качеством жизни - мы провели комплексное исследование «Жилищные условия семей крупного города» (2015-2016 гг.).

Эмпирической базой исследования выступили семьи Ульяновской области, которая занимает срединное положение в России по целому ряду социально-экономических показателей. Выборочная совокупность исследования составила 1150 респондентов; выборка репрезентативна по типам семей, возрастным и материальным характеристикам респондентов. Для анализа динамики использовались данные авторского регионального исследования «Социально-экономические характеристики уровня и качества жизни горожан» (2008 г.).

В качестве основных показателей характера потребностей в жилье мы рассматриваем: обеспеченность городских семей жильем, удовлетворенность жилищными условиями, стратегии изменения жилищных условий и способы их реализации. Авторское исследование показывает: обеспеченность жильем в последние годы меняется как в количествен- ных, так и качественных характеристиках. Большинство семей Ульяновска (92 \%) обеспечено своим жильем; оставшиеся $8 \%$ семей живут в общежитии или снимают жилье (табл. 4).

Сравнение с результатами регионального опроса 2008 г. показывает, что в Ульяновской области увеличилась доля семей, проживающих в частных домах и коттеджах (с 6 до $12 \%$; удельный вес проживающих в коммунальных квартирах, общежитиях и снимающих жилье остался примерно на том же уровне (в 2008 г. - $11 \%$, в 2015 г. - $13 \%$ ) [14, с. 37].

Жилищные условия городских семей очень дифференцированы:

- $12 \%$ семей живут в отдельном доме (коттедже) или части дома; чаще это состоятельные семьи (31\%) и бедные (19\%), что говорит о разном качестве частных застроек в городской черте (табл. 4);

- $75 \%$ семей живут в отдельной квартире, чаще жилой фонд ульяновцев представлен квартирами стандартных серий - 75-й и 90-й (37\%) или «хрущевками» (27\%). Чем ниже уровень жизни, тем чаще они проживают в устаревшем жилом фонде (75-82 \% бедных и малообеспеченных семей); около двух

Жилищные условия городских семей Ульяновской области

Таблица 4 (\% от числа опрошенных; $n=1150)$

\begin{tabular}{|c|c|c|c|c|c|c|c|c|c|c|c|c|}
\hline \multirow[b]{2}{*}{ Показатели } & \multicolumn{2}{|c|}{ Всего } & \multicolumn{5}{|c|}{ Тип семьи } & \multicolumn{5}{|c|}{ Уровень жизни } \\
\hline & 2008 & 2015 & $\begin{array}{c}\text { Только } \\
\text { из взрос- } \\
\text { лых лю- } \\
\text { дей тру- } \\
\text { доспо- } \\
\text { собного } \\
\text { возраста }\end{array}$ & $\begin{array}{c}\text { Моло- } \\
\text { дая се- } \\
\text { мья без } \\
\text { детей }\end{array}$ & $\begin{array}{c}\text { Родители } \\
\text { и дети } \\
\text { (до)школь- } \\
\text { ного воз- } \\
\text { раста }\end{array}$ & $\begin{array}{c}\text { Слож- } \\
\text { ная } \\
\text { много- } \\
\text { поко- } \\
\text { ленная } \\
\text { семья }\end{array}$ & $\begin{array}{c}\text { Люди } \\
\text { пен- } \\
\text { сион- } \\
\text { ного } \\
\text { воз- } \\
\text { раста }\end{array}$ & $\begin{array}{l}\text { Бед- } \\
\text { ные }\end{array}$ & $\begin{array}{c}\text { Мало- } \\
\text { обес- } \\
\text { печен- } \\
\text { ные }\end{array}$ & $\begin{array}{c}\text { Базо- } \\
\text { вые }\end{array}$ & $\begin{array}{c}\text { Сред- } \\
\text { ние }\end{array}$ & $\begin{array}{l}\text { Со- } \\
\text { стоя- } \\
\text { тель- } \\
\text { ные }\end{array}$ \\
\hline Проживание в... & & & & & & & & & & & & \\
\hline $\begin{array}{l}\text { отдельный дом / } \\
\text { коттедж }\end{array}$ & 4 & 8 & 9 & 3 & 7 & 14 & 12 & 8 & 8 & 5 & 13 & 21 \\
\hline $\begin{array}{l}\text { часть дома / } \\
\text { коттеджа }\end{array}$ & 2 & 4 & 5 & 4 & 3 & 6 & 8 & 11 & 2 & 2 & 5 & 10 \\
\hline $\begin{array}{l}\text { отдельная квар- } \\
\text { тира }\end{array}$ & 83 & 75 & 79 & 57 & 80 & 70 & 65 & 61 & 79 & 83 & 76 & 65 \\
\hline $\begin{array}{l}\text { комната в квар- } \\
\text { тире }\end{array}$ & 2 & 5 & 4 & 6 & 2 & 7 & 13 & 1 & 5 & 5 & 1 & 0 \\
\hline общежитие & 2 & 2 & 1 & 6 & 2 & 1 & 2 & 8 & 1 & 1 & 1 & 0 \\
\hline снимаю жилье & 7 & 6 & 3 & 24 & 6 & 2 & 1 & 11 & 9 & 4 & 4 & 4 \\
\hline Тип, серия дома & & & & & & & & & & & & \\
\hline индивидуальная & 7 & 13 & 14 & 7 & 12 & 21 & 13 & 7 & 10 & 6 & 21 & 36 \\
\hline улучшенная & 9 & 15 & 16 & 18 & 18 & 8 & 12 & 7 & 7 & 19 & 21 & 28 \\
\hline $\begin{array}{l}\text { стандартная се- } \\
\text { рия }(75 ; 90)\end{array}$ & 34 & 37 & 45 & 34 & 35 & 40 & 23 & 35 & 44 & 40 & 30 & 19 \\
\hline «хрущевка» & 36 & 27 & 21 & 37 & 22 & 20 & 48 & 38 & 35 & 26 & 17 & 3 \\
\hline «сталинка» & 5 & 4 & 1 & 7 & 6 & 8 & 3 & 3 & 3 & 5 & 9 & 14 \\
\hline «малосемейка» & 9 & 4 & 3 & 3 & 7 & 3 & 1 & 11 & 1 & 3 & 0 & 0 \\
\hline
\end{tabular}


третей состоятельных семей проживают в домах и квартирах индивидуальной или улучшенной застройки;

- $13 \%$ семей Ульяновска проживают в отдельных комнатах, общежитиях или снимают жилье; эти семьи следует отнести к группе риска на рынке недвижимости. В группу чаще попадают семьи, состоящие из молодых людей (36 \%), пенсионеров (16\%), а также семьи с душевым доходом на уровне прожиточного минимума или «бедные» $(20 \%)$.

Сравнение полученных результатов с данными общероссийских исследований показывает: проживающих в собственном жилье от арендаторов отличает возраст - приобретение жилой недвижимости становится результатом долгосрочных накопительных практик. Для старшего поколения приобретение жилья зачастую связано с программой приватизации жилья. Аренда жилья свойственна для этапа молодой семьи (прежде всего без детей); в последнее время он сопряжен не только с возрастом, но и с территориальной мобильностью молодежи [5, с. 120]. Для жителей региональных центров характерна мобильность в мегаполисы; для жителей районных центров и рабочих поселков - в региональные центры, где приобрести собственное жилье сложнее.
Удовлетворенность жилищными условиями является важным фактором формирования ориентаций и поведения на рынке недвижимости; она зависит от состава семьи и еще больше - от уровня жизни (табл. 5).

Для наглядного выявления тенденций по разным сегментам опрошенных мы «сжали» показатели и ввели индекс удовлетворенности жильем в диапазоне от +1 до -1 через присвоение каждому варианту ответа соответствующего коэффициента: полностью удовлетворен $(+1)$, в целом удовлетворен $(+0,5)$, скорее не удовлетворен $(-0,5)$, полностью не удовлетворен (-1). Среди ульяновских семей уровень удовлетворенности жильем - ниже среднего (среднее значение индекса равно 0,3; при максимальном значении 1; табл. 5).

Результаты исследования демонстрируют постепенный рост удовлетворенности населения жилищными условиями. В исследовании 2008 г. абсолютно или до известной степени удовлетворены $60 \%$ населения, 40 \% частично или полностью не удовлетворены. Факторами повышения удовлетворенности выступают проживание в малых городах, наличие высшего образования. Среди неудовлетворенных групп - прежде всего молодежь, вопрос приобретения жилья для этой группы особенно актуален.

Таблииа 5

Удовлетворенность семей Ульяновска жилищными условиями $(\% \text { от числа опрошенных; } n=1150)^{2}$

\begin{tabular}{|c|c|c|c|c|c|c|}
\hline \multirow[b]{2}{*}{ Показатели } & \multirow[b]{2}{*}{ Всего } & \multicolumn{5}{|c|}{ Уровень жизни } \\
\hline & & Бедные & $\begin{array}{l}\text { Мало- } \\
\text { обеспе- } \\
\text { ченные }\end{array}$ & $\begin{array}{c}\text { Базо- } \\
\text { вые }\end{array}$ & $\begin{array}{c}\text { Сред- } \\
\text { ние }\end{array}$ & $\begin{array}{l}\text { Состоя- } \\
\text { тельные }\end{array}$ \\
\hline \multicolumn{7}{|l|}{ Уровень удовлетворенности } \\
\hline Полностью удовлетворен & 18 & 15 & 12 & 18 & 21 & 36 \\
\hline В целом удовлетворен & 55 & 46 & 56 & 55 & 57 & 53 \\
\hline Скорее не удовлетворен & 20 & 26 & 25 & 19 & 18 & 6 \\
\hline Полностью не удовлетворен & 7 & 13 & 6 & 8 & 4 & 6 \\
\hline Индекс удовлетворенности & 0,3 & 0,1 & 0,2 & 0,27 & 0,4 & 0,5 \\
\hline \multicolumn{7}{|l|}{ Причины неудовлетворенности } \\
\hline Место проживания & 15 & 19 & 15 & 16 & 10 & 14 \\
\hline Экология зоны проживания & 17 & 17 & 11 & 16 & 24 & 26 \\
\hline Благоустройство двора & 29 & 26 & 28 & 32 & 25 & 25 \\
\hline Тип здания (материал) & 13 & 19 & 15 & 11 & 10 & 11 \\
\hline $\begin{array}{l}\text { Состояние здания } \\
\text { (изношенность, ветхость) }\end{array}$ & 15 & 24 & 20 & 16 & 7 & 7 \\
\hline $\begin{array}{l}\text { Оборудованность дома } \\
\text { (отопление, лифт, водоснабжение) }\end{array}$ & 15 & 24 & 19 & 15 & 12 & 3 \\
\hline Размер площади & 30 & 25 & 29 & 31 & 33 & 28 \\
\hline Количество проживающих & 13 & 15 & 16 & 12 & 13 & 6 \\
\hline
\end{tabular}


Тем не менее жилищный вопрос для значительной части населения не решен, в том числе по качественным причинам. Причины неудовлетворенности жилищными условиями различны (см. табл. 5); мы сгруппировали их в три блока. Первый блок - эколого-географические причины. Самый весомый сегмент причин неудовлетворенности, их разделяют $61 \%$ семей. К этим причинам относятся: неудовлетворенность местом проживания - $15 \%$ (районом, микрорайоном); плохая экология ближайшей зоны - $17 \%$; отсутствие благоустройства двора - 29 \%. К экологии больше претензий у семей со средним достатком и состоятельных семей; к благоустройству дворов - у родителей с детьми и пенсионеров.

Второй блок - социально-функциональные причины; к ним относятся: неудовлетворенность типом здания - $13 \%$ (материал, технология), состоянием дома - 15 \% (изношенность, ветхость), оборудованностью дома $15 \%$ (отопление, работа лифта, водоснабжение). В целом данные претензии высказали $43 \%$ опрошенных семей. Особенно остро стоят проблемы ветхости и изношенности домов, в которых проживают бедные и малообеспеченные семьи. Ульяновск внесен в список городов, осуществляющих ремонт ветхого жилья с большим отставанием.

Третий блок- количественно-функциональные причины: неудовлетворенность размером площади - 30 \% (особенно - молодые семьи, родители с детьми, многопоколенные семьи); количеством проживающих людей - 13 \% (чаще - большие, многопоколенные семьи).

Сравнение объективных стандартов уровня и качества жизни с субъективным ощущением стесненности проживания свидетельствует о том, что семьи адаптировались к реальным условиям проживания и не считают их очень плохими - «живем как все». Ситуация отражает сложившийся у старшего поколения россиян невысокий уровень требований; многие представители среднего класса в регионах живут в домах стандартного типа. В развитых европейских государствах, напротив, субъективные показатели удовлетворенности гораздо критичнее объективных индикаторов условий проживания; в этом контексте Российская Федерация близка к постсоциалистическим странам [20, p. 37].
Социологические исследования в регионах России показывают, что тесное жилье характерно для большинства многопоколенных семей. В таких домохозяйствах на одной площади проживают родительская семья и семьи взрослых детей. Иждивенческая нагрузка осложняет решение квартирного вопроса. Соответственно, наиболее обеспеченные качественным жильем группы - молодые люди и проживающие отдельно от детей представители старшего поколения. Причем важен не факт наличия просторного жилья, а запас ресурсов, который позволял бы молодым людям создавать семью, иметь детей, не сталкиваясь с проблемой дефицита жилья. При этом всероссийское исследование «Человек. Семья. Общество» показывает: для взрослого респондента в возрасте до 36 лет вероятность совместного проживания с родителями в полтора раза выше вероятности его отдельного проживания. Отсутствие необходимого «запаса прочности» и ресурсов для решения жилищного вопроса подтверждается дефицитом жилья у семей с несовершеннолетними детьми [4, с. 279].

Анализ причин неудовлетворенности жилищными условиями свидетельствует о том, что у жителей Ульяновской области есть свои претензии к состоянию жилого фонда, как количественные, так и качественные. Уровень неудовлетворенности благоустройством территории, энерго- и водообеспечением, доступностью объектов социального назначения способствовал тому, что в Ульяновске выше уровень критических настроений в изучаемой сфере, чем в среднем по России (см. табл. 6).

Более высокую активность на рынке недвижимости демонстрируют отдельные сегменты городского населения:

- семьи, состоящие из молодых людей; $37 \%$ от общей доли этих семей планируют купить новое жилье (см. табл. 7). В первую очередь это покупка отсутствующего жилья (почти половина от потенциальных потребителей - $47 \%$ ); во вторую - расширение (более четверти - $27 \%$ );

- семьи из среднедоходной страты; треть (33\%) таких семей в Ульяновске планирует в ближайшее время совершить действия на рынке недвижимости, направленные, прежде всего, на приобретение отдельного 
Сравнительный анализ уровня удовлетворенности жилищными условиями семей Ульяновской области и РФ (\% от числа опрошенных; $n 1=1150, n 2=1500)$

\begin{tabular}{|l|c|c|}
\hline \multicolumn{1}{|c|}{ Удовлетворенность } & Ульяновская область & РФ * \\
\hline Удовлетворены полностью & 18 & 34 \\
\hline Удовлетворены частично & 55 & 48 \\
\hline Не удовлетворены & 27 & 16 \\
\hline
\end{tabular}

Примечание. *-источник: [6].

Планы семей в приобретении жилья (\% от числа опрошенных; $n=1150)$ *

\begin{tabular}{|c|c|c|c|c|c|c|c|c|c|c|c|}
\hline \multirow[b]{2}{*}{ Показатели } & \multirow[b]{2}{*}{ Всего } & \multicolumn{5}{|c|}{ Тип семьи } & \multicolumn{5}{|c|}{ Уровень жизни } \\
\hline & & $\begin{array}{c}\text { Только } \\
\text { из взрос- } \\
\text { лых лю- } \\
\text { дей тру- } \\
\text { доспо- } \\
\text { собного } \\
\text { возраста }\end{array}$ & $\begin{array}{l}\text { Моло- } \\
\text { дая се- } \\
\text { мья без } \\
\text { детей }\end{array}$ & \begin{tabular}{|c} 
Родители и \\
дети \\
(до)школь- \\
ного воз- \\
раста
\end{tabular} & $\begin{array}{c}\text { Слож- } \\
\text { ная } \\
\text { много- } \\
\text { поко- } \\
\text { ленная } \\
\text { семья }\end{array}$ & $\begin{array}{c}\text { Люди } \\
\text { пен- } \\
\text { сион- } \\
\text { ного } \\
\text { воз- } \\
\text { раста }\end{array}$ & $\begin{array}{l}\text { Бед- } \\
\text { ные }\end{array}$ & $\begin{array}{l}\text { Мало- } \\
\text { обеспе- } \\
\text { ченные }\end{array}$ & $\begin{array}{c}\text { Базо- } \\
\text { вые }\end{array}$ & $\begin{array}{c}\text { Сред- } \\
\text { ние }\end{array}$ & $\begin{array}{l}\text { Со- } \\
\text { стоя- } \\
\text { тель- } \\
\text { ные }\end{array}$ \\
\hline \multicolumn{12}{|c|}{ Планы на приобретение жилья } \\
\hline Да, планируем & 23 & 21 & 37 & 21 & 26 & 8 & 18 & 18 & 22 & 33 & 29 \\
\hline Нет, не планируем & 51 & 55 & 39 & 45 & 50 & 76 & 53 & 54 & 46 & 51 & 58 \\
\hline Трудно сказать & 26 & 24 & 25 & 34 & 23 & 17 & 29 & 28 & 32 & 16 & 13 \\
\hline \multicolumn{12}{|c|}{ Цели приобретения жилья } \\
\hline $\begin{array}{l}\text { Приобретение от- } \\
\text { сутствующего } \\
\text { жилья }\end{array}$ & 23 & 12 & 47 & 18 & 6 & 0 & 2 & 24 & 35 & 10 & 6 \\
\hline $\begin{array}{l}\text { Приобретение от- } \\
\text { дельного жилья }\end{array}$ & 35 & 52 & 16 & 18 & 61 & 50 & 85 & 24 & 26 & 44 & 12 \\
\hline $\begin{array}{l}\text { Замена ветхого } \\
\text { жилья }\end{array}$ & 13 & 8 & 14 & 2 & 28 & 23 & 54 & 17 & 4 & 2 & 0 \\
\hline $\begin{array}{l}\text { Расширение пло- } \\
\text { щади }\end{array}$ & 31 & 19 & 27 & 59 & 22 & 0 & 31 & 27 & 26 & 41 & 33 \\
\hline $\begin{array}{l}\text { Приобретение } \\
\text { второго жилья }\end{array}$ & 8 & 12 & 3 & 2 & 11 & 25 & 0 & 7 & 9 & 12 & 34 \\
\hline $\begin{array}{l}\text { Вложение денеж- } \\
\text { ных сбережений } \\
\text { в недвижимость }\end{array}$ & 1 & 13 & 2 & 1 & 0 & 2 & 0 & 0 & 1 & 4 & 15 \\
\hline
\end{tabular}

Примечание. *-ответ на вопрос предполагал многовариантность, поэтому сумма ответов по каждому столбцу превышает $100 \%$.

жилья или расширение (44 и $41 \%$ от средней страты соответственно);

- состоятельные семьи; каждая третья семья планирует в ближайшее время купить жилую площадь с целью расширения общей площади (32\% от данного сегмента), приобретения второго жилья (34 \%) или вложения средств в недвижимость (15\%);

- сложные многопоколенные семьи; каждая четвертая семья этого типа (26 \%) планирует купить жилую площадь с целью приобретения отдельного жилья или замены ветхих условий проживания.

Планируя приобретение жилья, семьи рассчитывают не только на уже имеющиеся у них средства. По данным, представленным Росстатом (комплексное наблюдение условий жизни населения РФ), в 2014 г. были определены и оценены предполагаемые источники денежных средств на приобретение или строительство жилья домохозяйствами. Такими источниками были: субсидии на приобретение жилья $(4,2 \%$ семей используют этот механизм); средства материнского капитала (20,8 \%); продажа имеющегося жилья для покупки другого $(37,1 \%)$; ипотечный кредит $(45,4 \%)$; другие источники, в том числе собственные средства $(39,5 \%)$.

Проведенное исследование показывает: молодежь в первую очередь ориентируется на способы улучшения жилищных условий, требующие достижения статуса или наличия определенного стартового капитала. Молодые люди, которые не в состоянии самостоятель- 
но решить жилищный вопрос, чаще рассчитывают на родителей. На этой почве возникают межпоколенческие конфликты.

Выявленную нами тенденцию подтверждает исследование в Кировской области: между родственниками портятся отношения из-за наследования жилья; родители оценивают жилищные условия детей как «меньшие по метражу и худшие по качеству, объясняя миграцией молодого поколения из села в город, из малых городов в крупные города и мегаполисы [12, с. 58]. Миграции детей не дают родителям возможности «конвертировать свою жилищную собственность в равнозначную, чтобы помочь детям в решении жилищного вопроса или чтобы жить к ним поближе. В наиболее выгодном положении оказываются те, чье старшее поколение живет в крупных городах».

Молодые семьи являются самыми активными на рынке жилья, но и самыми уязвимыми. Как показывают результаты нашего исследования, большинство молодых семей планирует рождение детей только после того, как произойдет решение жилищного вопроса. В свою очередь, предоставление поддержки молодым семьям находится в прямой зависимости от поддержки на региональном уровне. Молодые семьи становятся уязвимыми и в силу субъективных причин: недостаточная информированность о возможностях улучшения жилищных условий, низкий уровень платежеспособности, отсутствие собственных средств для приобретения жилья и просто первоначального капитала.

Соединение объективных и субъективных факторов выводит жилищные условия в число детерминант, с которыми связано социальное самочувствие в целом. Соотношение оценок молодых людей, связанных с жилищными условиями и успехами в жизни, свидетельствует о наличии корреляций: неудовлетворенные собственным или родительским жильем молодые люди менее успешны в жизни; напротив, полная удовлетворенность жилищными условиями более тесно коррелирует с признанием социальной успешности. Жилищные условия выступают интегрированным показателем «жизненных условий», то есть объединения уровня и качества жизни.
Bblвoдbl. При анализе качества жизни наиболее важной и реально наблюдаемой характеристикой выступает степень удовлетворенности индивидов и семей условиями жизни, а также полнотой реализации жизненных планов в этих условиях. Жилье и его комфортность занимают среди факторов достижения качества жизни ведущую позицию.

Анализ жилищных условий в российских регионах показал, что в большинстве социально-демографических, социально-экономических сегментов населения есть потребность в улучшении жилья. Запросы в изменении жилищного статуса выражают молодые люди и многопоколенные семьи; но именно у них нет необходимых средств для решения этого вопроса. В ходе исследования выявлены разные представления о качестве жизни в различных поколениях: представители старшего поколения менее требовательны и чаще готовы жить, как все; молодежь стремится получить основные жизненные блага сразу по высшим критериям.

Установки населения на повышение качества жизни являются ориентиром для федеральных и региональных органов власти: несмотря на высокую обеспеченность собственным жильем, развитие его качественных характеристик и повышение комфортности находится в начальной стадии.

\section{ПРИМЕЧАНИЕ}

${ }^{1}$ Статья подготовлена при поддержке РГНФ, проект «Доступность жилья как идентификатор качества жизни в регионе» № 16-13-73601.

\section{СПИСок ИСТочников}

1. Аристотель. Политика / Аристотель // Сочинения : в 4 т. - М. : Мысль, 1983. - Т. 4. -830 с. C. $376-644$.

2. Ахметшина, Е. Р. Образ жизни и социальное самочувствие свободно занятых работников: межрегиональное сравнение / Е. Р. Ахметшина, Т. В. Клюева, О. В. Полетаев // Вестник Московского университета. Серия 18 , Социология и политология. - 2016. - № 4. - С. 200-214.

3. Беляева, Л. А. Уровень и качество жизни. Проблемы измерения и интерпретации / Л. А. Беляева // Социологические исследования. - 2009. № 1. - C. 33-42. 
4. Бурдяк, А. Я. Обеспеченность жильем в постсоветской России: неравенство и проблема поколений / А. Я. Бурдяк // Журнал исследований социальной политики. - 2015. - Т. 13, № 2. - С. 273-288.

5. Караваева, Е. Ю. Жилищные отношения, политика и условия / Е. Ю. Караваева, Т. Ю. Черкашина // Мониторинг общественного мнения: экономические и социальные перемены. - 2015. № 6 (130). - С. 118-135.

6. Квартирный вопрос: Результаты опроса Фонда общественного мнения. 2014 г. - Электрон. текстовые дан. - Режим доступа: http://fom.ru/ Rabota-i-dom/11356 (дата обращения: 26.06.2017). Загл. с экрана.

7. Методический подход к измерению качества жизни населения региона / О. А. Козлова, Т. В. Гладкова, М. Н. Макарова, Е. Х. Тухтарова // Экономика региона. -2015. - №2 (42). - С. 182-193.

8. Нагимова, А. М. Социологический анализ качества жизни населения: региональный аспект / А. М. Нагимова. - Казань : Казан. гос. ун-т, 2010. $306 \mathrm{c}$.

9. Прожиточный минимум, бедность и богатство в представлениях россиян: результаты исследования «Левады-Центра». - Электрон. текстоые дан. - Режим доступа: http:/www.levada.ru/2013/08/08/ prozhitochnyj-minimum-bednost-i-bogatstvo-vpredstavleniyah-rossiyan (дата обращения: 26.06.2017). Загл. с экрана.

10. Российский статистический ежегодник. 2016 : стат. сб. - М. : Росстат, 2016. - 725 с.

11. Социально-экономические индикаторы бедности в 2012-2015 годах, 2016 г. - Электрон. текстовые дан. - Режим доступа: http:/www.gks.ru/ wps/wcm/connect/rosstat_main/rosstat/ru/statistics/ publications/catalog/doc_1252310752594 (дата обращения: 26.06.2017). - Загл. с экрана.

12. Старикова, М. М. Практики решения жилищного вопроса в современном городе (на примере г. Кирова) / М. М. Старикова // Социология города. - 2014. - № 3. - С. 48-65.

13. Толстых, И. А. Принципы реализации ипотечного жилищного кредитования для повышения уровня и качества жизни населения / И. А. Толстых // Инновационная экономика: перспективы развития и совершенствования. - 2016. - № 1 (13). С. 263-269.

14. Шиняева, О. В. Потребности населения и емкость рынка жилищного строительства в регионе / О. В. Шиняева, Т. В. Клюева // Вестник Ульяновского государственного технического университета. - 2016. - № 4. - C. 36-39.

15. America's Rental Housing: Evolving Markets and Needs. - Washington : The U. S. Department of Housing and Urban Development, 2013. - Electronic text data. - Mode of access: http://www.jchs.harvard.edu/ sites/jchs.harvard.edu/files/jchs_americas_rental housing_2013_1_0.pdf(date of access: 26.07.2017). - Title from screen.

16. Galbraith, J. K. The Affluent Society / J. K. Galbraith. - Boston : Houghton Mifflin, 1998.$288 \mathrm{p}$.

17. Hulchanski, J. D. The concept of housing affordability: Six contemporary uses of the housing expenditureto-income ratio / J. D. Hulchanski // Housing Studies. - 1995. - Vol. 10, iss. 4. - P. 471-497.

18. Luffman, J. Measuring housing affordability / J. Luffman // Statistics Canada. Perspectives. - 2006. Vol. 11. - P. 16-25.

19. Pigou, A. The Economics of Welfare / A. Pigou. - L. : Palgrave-Macmillan, 2013. - 896 p.

20. Sunega, P. Subjective or objective? What matters? / P. Sunega // Critical Housing Analysis. 2014. - Vol. 1. - P. 35-43.

21. World Cities Report 2016: Urbanization and Development - Emerging Futures. - L. : Sterling, VA, United Nations Human Settlements Programme, 2016. $262 \mathrm{p}$.

\section{REFERENCES}

1. Aristotel. Politika [Aristotle. Politics]. Sochineniya: $v 4 t$. [Works in 4 vols.]. Moscow, Mysl Publ., 1983, vol. 4, pp. 376-644.

2. Akhmetshina E.R., Klyueva T.V., Poletaeva O.V. Obraz zhizni i sotsialnoe samochuvstvie svobodno zanyatykh rabotnikov: mezhregionalnoe sravnenie [Lifestyle and Social Well-Being of Freelancers: an Interregional Comparison]. Vestnik Moskovskogo universiteta. Seriya 18, Sotsiologiya i politologiya, 2016, no. 4, pp. 200-214.

3. Belyaeva L.A. Uroven i kachestvo zhizni. Problemy izmereniya i interpretatsii [Living Standards. Challenges of Measuring and Interpretation]. Sotsiologicheskie issledovaniya [Sociological Studies], 2009, no. 1, pp. 33-42.

4. Burdyak A.Ya. Obespechennost zhilyem v postsovetskoy Rossii: neravenstvo i problema pokoleniy [Housing in Post-Soviet Russia: Inequality and the Problem of Generations]. Zhurnal issledovaniy sotsialnoy politiki, 2015, vol. 13, no. 2, pp. 273-288.

5. Karavaeva E.Yu., Cherkashina T.Yu. Zhilishchnye otnosheniya, politika i usloviya [Housing Relations, Politics and Conditions]. Monitoring obshchestvennogo mneniya: ekonomicheskie $i$ sotsialnye peremeny, 2015, no. 6 (130), pp. 118-135.

6. Kvartirnyy vopros: Rezultaty oprosa Fonda obshchestvennogo mneniya. $2014 \mathrm{~g}$. [Housing Issue: Results of Public Opinion Fund Survey. 2014]. URL: http://fom.ru/Rabota-i-dom/11356. (accessed June 26, 2017). 
7. Kozlova O.A., Gladkova T.V., Makarova M.N., Tukhtarova E.Kh. Metodicheskiy podkhod k izmereniyu kachestva zhizni naseleniya regiona [Methodical Approach to Measuring the Life Quality in the Region]. Ekonomika regiona, 2015, no. 2 (42), pp. 182-193.

8. Nagimova A.M. Sotsiologicheskiy analiz kachestva zhizni naseleniya: regionalnyy aspekt [Sociological Analysis of the Quality of Life of Population: Regional Aspect]. Kazan, KGU Publ., 2010. $306 \mathrm{p}$.

9. Prozhitochnyy minimum, bednost i bogatstvo v predstavleniyakh rossiyan: rezultaty issledovaniya «Levada-tsentr» [The Subsistence Level, Poverty and Wealth in Representations of the Russians: Results of the Study, Levada-Center]. URL: http://www.levada.ru/ 2013/08/08/prozhitochnyj-minimum-bednost-ibogatstvo-v-predstavleniyah-rossiyan. (accessed June 26, 2017).

10. Rossiyskiy statisticheskiy ezhegodnik [Russian Statistical Yearbook]. Moscow, Rosstat Publ., 2016. 725 p.

11. Sotsialno-ekonomicheskie indikatory bednosti v 2012-2015 godakh, 2016 g. [SocioEconomic Indicators of Poverty in 2012-2015. 2016]. URL: http://www.gks.ru/wps/wcm/connect/rosstat main/rosstat/ru/statistics/publications/catalog/doc 1252310752594 (accessed June 26, 2017).

12. Starikova M.M. Praktiki resheniya zhilishchnogo voprosa $\mathrm{v}$ sovremennom gorode (na primere g. Kirova) [Practice of Solving the Housing Problem in the Modern City (the Case Study of Kirov)]. Sotsiologiya goroda, 2014, no. 3, pp. 48-65.

13. Tolstykh I.A. Printsipy realizatsii ipotechnogo zhilishchnogo kreditovaniya dlya povysheniya urovnya i kachestva zhizni naseleniya [Principles of Implementation of Mortgage Lending to Increase the Level and Quality of Life]. Innovatsionnaya ekonomika: perspektivy razvitiya $i$ sovershenstvovaniya [Innovative Economy: Prospects for Development and Improvement], 2016, no. 1 (13), pp. 263-269.

14. Shinyaeva O.V., Klyueva T.V. Potrebnosti naseleniya i emkost rynka zhilishchnogo stroitelstva $\mathrm{v}$ regione [Demands of Population and the Capacity of Housing Construction Market in the Region]. Vestnik Ulyanovskogo gosudarstvennogo tehnicheskogo universiteta, 2016, no. 4, pp. 36-39.

15. America's Rental Housing: Evolving Markets and Needs. The American Housing Survey, the Census Bureau; The U. S. Department of Housing and Urban Development. Washington, 2013. URL: http://www.jchs.harvard.edu/sites/jchs.harvard.edu/ files/jchs_americas_rental_housing_2013_1_0.pdf. (accessed June 26, 2017).

16. Galbraith J.K. The Affluent Society. Boston, Houghton Mifflin, 1998. 288 p.

17. Hulchanski J.D. The concept of housing affordability: Six contemporary uses of the housing expenditure to-income ratio. Housing Studies, 1995, vol. 10, iss. 4, pp. 471-497.

18. Luffman J. Measuring housing affordability. Statistics Canada. Perspectives, 2006, vol. 11, pp. 16-25.

19. Pigou A. The Economics of Welfare. London, Palgrave-Macmillan, 2013.896 p.

20. Sunega P. Subjective or objective? What matters? Critical Housing Analysis, 2014, vol. 1, pp. 35-43.

21. World Cities Report 2016: Urbanization and Development - Emerging Futures. London, Sterling, VA, United Nations Human Settlements Programme, 2016. 262 p.

\section{Information about the Authors}

Olga V. Shinyaeva, Doctor of Sociological Sciences, Professor, Head of Department of Political Science, Sociology and Public Relations, Ulyanovsk State Technical University, Severnyy Venets St., 32, 432027 Ulyanovsk, Russian Federation, olses@rambler.ru.

Ekaterina R. Akhmetshina, Candidate of Sociological Sciences, Associate Professor, Department of Political Science, Sociology and Public Relations, Ulyanovsk State Technical University, Severnyy Venets St., 32, 432027 Ulyanovsk, Russian Federation, katerina.akhmetshina@rambler.ru.

Tatyana V. Klyueva, Candidate of Sociological Sciences, Associate Professor, Department of Political Science, Sociology and Public Relations, Ulyanovsk State Technical University, Severnyy Venets St., 32, 432027 Ulyanovsk, Russian Federation, klyueva@list.ru.

\section{Информация об авторах}

Ольга Викторовна Шиняева, доктор социологических наук, профессор, заведующая кафедрой политологии, социологии и связей с общественностью, Ульяновский государственный технический университет, ул. Северный Венец, 32, 432027 г. Ульяновск, Российская Федерация, olses@rambler.ru. 


\section{СОЦИОЛОГИЯ И СОЦИАЛЬНЫЕ ТЕХНОЛОГИИ}

Екатерина Рифовна Ахметшина, кандидат социологических наук, доцент кафедры политологии, социологии и связей с общественностью, Ульяновский государственный технический университет, ул. Северный Венец, 32, 432027 г. Ульяновск, Российская Федерация, katerina.akhmetshina@rambler.ru.

Татьяна Валерьевна Клюева, кандидат социологических наук, доцент кафедры политологии, социологии и связей с общественностью, Ульяновский государственный технический университет, ул. Северный Венец, 32, 432027 г. Ульяновск, Российская Федерация, klyueva@list.ru. 